\title{
The Staicu lexicon in relation to lexicons belonging to the Berynda family: orthography and structure ${ }^{\dagger}$
}

\author{
Ion-Mihai Felea ${ }^{\star}$ \\ Faculty of Letters, "Alexandru Ioan Cuza" University, Bd. Carol I 11, 700506 Iași, Romania
}

\section{Article info}

History:

Received May 12, 2021

Accepted July 5, 2021

Published August 18, 2021

Key words:

historical lexicology comparative analysis

\begin{abstract}
The first manuscripts with Slavonic-Romanian dictionaries date from the $17^{\text {th }}$ century and six of these have been preserved to the present day almost intact. They are all based on Pamvo Berynda's lexicon (1627), to which several word lists were added in some of the manuscripts. These manuscripts have mostly been studied from a lexical point of view.

Our study aims at describing the way in which the lexicons were elaborated, at observing the significant orthographic variations and also at becoming an additional tool for establishing the network of filiations from which the Romanian lexicons resulted. Our observations focus on the entries for the first three letters in the above-mentioned lexicons. As all these lexicons were available in electronic format, we identified the propagation of several errors in the Romanian antigraphs, emphasized various aspects related to spelling and compared the additional lists.

The data indicates that Romanian manuscripts preserve the orthography of Berynda's Lexicon and the additional lists to a different degree. These variations suggest the existence of at least one protograph between the source and the Romanian lexicons. Applied to the entire content of the manuscripts, the investigation of these variations could contribute to the identification of the manuscript that is the closest to the initial version.
\end{abstract}

\section{Introduction}

The "Berynda family" designates the Slavonian-Ruthenian lexicon of Pamvo Berynda [= BER], printed for the first time in 1627 in Kiev, as well as a group of Slavonic-Romanian lexicons from the $17^{\text {th }}$ century which were based on the Ruthenian edition. The following works are included: The Staicu Lexicon (Romanian manuscript 312 BAR, mentioned in our study as Lex.Sta.), the lexicon in Romanian manuscript 1348 BAR written by Mihai Logofătul (= Lex.1348), the lexicon in Romanian manuscript 3473 BAR copied by a certain Mihaiu (= Lex.3473), the lexicon of Petersburg (OP Q.XVI.5 BNR, mentioned in our study as Lex.Pet.), the lexicon of Mardarie in the Romanian manuscript 450 BAR (= Lex.Mard.) and the lexicon of Moscow (F. 188, Op. 1. nr. 1383, RGADA, mentioned in our study as Lex.Mosc.). The Romanian manuscripts have benefitted of inconsistent attention throughout the years, mainly because of the fact that two of them are located in Russia. Although the list is far from thoroughgoing, we should mention that Lex.Mard. was edited by Crețu (1900) in a volume that still proves useful, whereas Lex.Mosc. was partly studied by Ciobanu (1914). Lex.Sta. and its author were studied by Strungaru (1973) and Gînsac \& Ungureanu (2019). Overall perspectives were provided by Strungaru (1966), Аевичкин \& Сухачев (2015) and Gînsac \& Ungureanu (2018). Since the above-mentioned works focused primarily on the lexical component of the dictionaries, we considered that the filiation should also be approached from the less exploited perspective of orthography. Several manuscripts have become accessible through

†This paper was funded by a grant provided by the Romanian Ministry of Research, Innovation and Digitalization, CNCS/CCCDI - UEFISCDI, project no. PN III-P1.1-TE-2019-0517, within the PNCD III programme.

${ }^{\star}$ Email address: imfelea@gmail.com. 
digitization processes, more information is available about the orthographic norms of the time, and fonts such as those created within the Ponomar project ${ }^{1}$ provide us with an opportunity to explain differences that used to be overlooked. Our secondary aim was to catalogue those divergences that cannot be explained solely by the degree of freedom that scholars took when copying from one manuscript to another.

Before the issue of the complete comparative edition we intend to elaborate within the eRomLex project (see scriptadacoromanica.ro), this study used the material for the first three letters: $\mathbf{A}, \mathbf{G}$ and $\mathbf{R}$. All the Slavonic words were transcribed taking into account the whole range of orthographic details whenever fidelity was deemed necessary. The translations from the Romanian manuscripts are rendered in Italics.

\section{Structure}

The Staicu Lexicon, which can be found on pages $41^{\mathrm{v}}-216^{\mathrm{v}}$ of the Romanian manuscript 312 BAR, represents a collaborative endeavour of several people. It contains around 6,000 proper names, Slavonic common nouns and a smaller percentage of Greek and Hebrew nouns listed according to the Slavonic alphabet. Towards the end, it includes two additional wordlists, considerably shorter than the basic lexicon. These are followed by a series of thematic lexical lists, such as the translation of animal names from Lev, 11. The basic lexicon is an adaptation of the BER, with a few notable differences. Compared to the Ruthenian edition, the proper names are listed immediately after the common ones, not separately. The second notable difference is the fact that after the material in BER, each letter contains at least one page of content that is independent from the Ruthenian lexicon. These additional entries were definitely written by the same hand and most of them are Slavonic, Russian and Ruthenian words. Further on we shall use the convention $S_{t a i c u}$ for the definitions with an equivalent in BER, whereas the ones copied from an unidentified source shall be considered written by $\mathrm{Staicu}_{2}$, without overlooking the fact that this is actually the same person. The content taken from BER by $S_{\text {taicu }}$ varies, yet for certain letters it is retrieved almost completely. The words written by $\mathrm{Staicu}_{2}$ are arranged almost alphabetically, meaning that they appear in groups of 3-5 words listed in alphabetical order, between which some words that do not seem to be in the right place were added. This apparently chaotic organization could be explained in relation to other types of early lexicons. It is possible that our lexicons completed the lexical lists in Berynda with entries taken from one or several Slavonic proto-dictionaries. In order to justify this hypothesis, a variety of information can be considered. This hypothesis is supported by information on the structure of medieval lexicons, which were not always arranged according to the expectations one may have today with regard to a dictionary (Ковтун, 1989, p. 23). A common method was to organize the entries in chapters where words were grouped according to their initial and the second vowel they contained (Карпов, 1877, p. 137); in other cases, the definitions were separated according to thematic categories: months of the year, body parts, proper names, plants, etc. The first principle could explain why in Lex.Sta. we come across successive

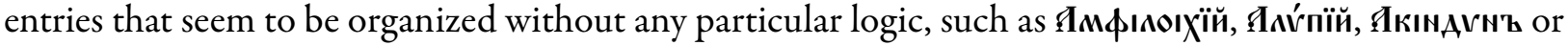
Iрте́мъ, Яве́ркїй, Яре́,

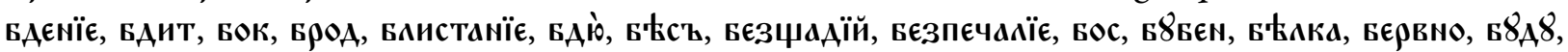
в8 BER. If we accept that Блистанї is a paradigm supplement for Бл'кск'ъ and reconstruct the historical forms

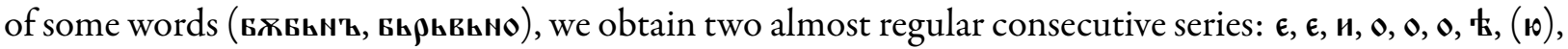

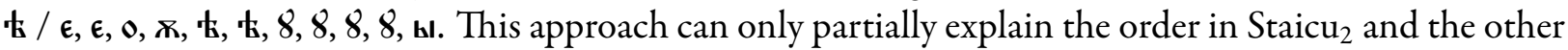
Romanian manuscripts, respectively; however, if this hypothesis proves to be true, it indicates that the entries in $\mathrm{Staicu}_{2}$ were copied from at least one early Slavonic lexicon. The definitions copied by Staicu 2 do not seem to be grouped thematically, yet some of them appear where one would expect to find them in a thematic dictionary. For instance, at the end of $\mathbf{6}$, we find the succession вонифантий, ворис, вори, $\mathbf{z}$. The proper names categories are also placed at the end of the entries for one letter in other Slavonic dictionaries (Карпов, 1877, p. 136; for the classification of Russian lexicons, see Ковтун, 1989, p. 9). A similar

\footnotetext{
${ }^{1}$ Information on the mission and achievements of the project is available at ponomarnet.
} 
pseudo-alphabetical order can be found in manuscript no. 1649 of the Pogodin collection belonging to the Russian National Library, a small lexicon dating from mid- $16^{\text {th }}$ century ${ }^{2}$. We therefore believe that it is possible for the translation from Staicu $\mathrm{S}_{2}$ to have been done after a manuscript which was similar in form and content to the ones that appeared in the Russian area starting with the $15^{\text {th }}$ century. To provide such an example we shall refer to the entry вори, $\mathbf{z}$ (translated $o$ iarbă ascuțită la miros [a sharp-smelling type of grass] in Lex.Mosc., Lex.1348, and o iarbă iute la miros [a pungent-smelling type of grass] in Lex.Sta.), relating it to Sergey's lexicon, a manuscript copied around the year 1650 at the Russian Solovetsky Monastery ${ }^{3}$ and described by $\Lambda$ евичкин \& Сухачев (2015, p. 440) as the most comprehensive Russian medieval lexicon. Sergey's lexicon has the structure described above and section Eo includes the entry

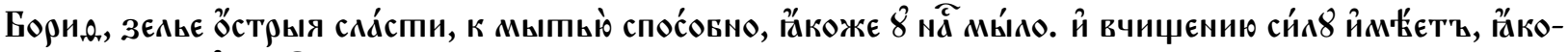

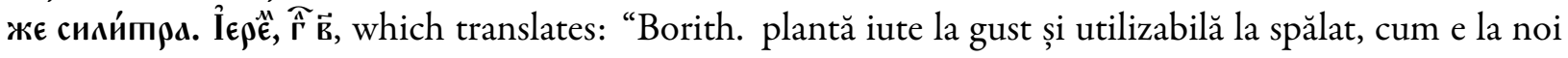
săpunul, și putere de curățare are precum silitra. Ierem 2" [Borith. A sharp-tasting plant that can be used for washing, as we use soap, which cleans as well as salpetre. Jerem 2]. We can thus infer that two of our lexicons selected the first meaning of острый, namely 'ascuțit' [sharp], whereas Staicu opted for the other meaning, which is more appropriate 'iute' [pungent], either because he had the Slavonic text in front of him or because he understood the source of the error. Бори, and a few other adjacent entries are missing from Lex.1348, yet the latter still contains around 30 definitions that are not recorded in other manuscripts. This entry cannot be found in either Lex.Mard. or Lex.Pet.

Obviously, the source of the definitions copied by Staicu 2 cannot possibly be Sergey's lexicon, yet the fact that most entries for $\mathbf{E}$ can also be found, although in a different order, in the Russian manuscript, is still relevant. It is possible that they were part of a common body of definitions that migrated from one Slavonic lexicon to the other, in some instances becoming simpler, as in the Romanian manuscripts and in others gaining an encyclopaedic character, as in the Solovetsky dictionary. These additional lists from Staicu do not necessarily originate from the same source. In Lex.Mard. the letter $\mathbf{E}$ ends with the entries БОдєЦь, БОАєнєЦь and БОдєЖ. In his lexicon, Staicu 2 draws the line after the last entry in the succession

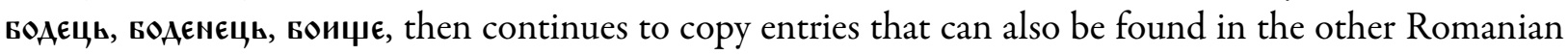
lexicons. We cannot be certain that $\mathrm{Staicu}_{2}$ used two different lists, but the line can as well signal the end of a list that was related to Lex.Mard.

\section{The scribes of the Staicu lexicon}

Besides the text of the scribe, the lexicon was modified by several readers. Some of these interventions consisted in definitions or observations inserted sporadically, while others produced consistent changes regarding the content of the dictionary. It is difficult to assess how many people contributed to the content of the manuscript, as the handwriting style can be modified by several factors: the writing instrument, the type of intervention - side note, end note or restoration of the manuscript, the language in which it is written.

\subsection{The Lupaşcu hand}

The first two pages of letter A, between Яззи and Ягрипнїл, were written by the same hand. According to a note on page $41^{v}$ from May, 1, 1758, the manuscript was owned by a certain priest, Lupașcu. Although the orthography is much neater, one can recognize in it the hand that will add numerous entries to the lexicon. Page $41^{\mathrm{v}}$ was left half blank and subsequently another hand added some etymological notes. Definitions 1-9, up to ЯАчва, can also be found in BER. The others, up to Ягрипнїл, were most probably copied from another manuscript, with little connection to BER. This conclusion is supported by: the approximate alphabetical order, the extremely tenuous selection, if it were to be explained through BER,

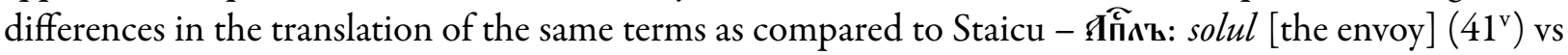

\footnotetext{
${ }^{2}$ The digital format of the text is available here: oldlexicons.ru.

${ }^{3}$ The RNB site provides an excellent digital copy under listing OP Cos. 18/18 (nlr.ru).
} 


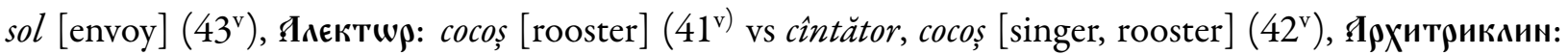
nunul, mai marele nuntei [groomsman, overseer of a wedding] $\left(41^{\mathrm{v}}\right)$ vs nunul [groomsman] $\left(44^{\mathrm{r}}\right)$ and Inавастр: sticlă, marmură [glass, marble] vs șip de sticlă sau de marmură [bottle made of glass or marble] $\left(42^{\mathrm{v}}\right)$, the entry Пгав'ъ. Iгавїє and Ягав'ъ are probably different saints, as in Lex.Mosc., Lex.Pet. and Lex.Sta. there is at least one entry that coincides with Berynda for Фгавъ, while the translations differ (Ігавïє: batjocură [taunt / scorn] as opposed to Пгавъ: luminat [enlightened]).

Lupaşcu also left some lexicographic attempts in the form of small groups of words on the pages that precede the lexicon. Many of these have a correspondent in BER, yet some are obviously Ruthenian,

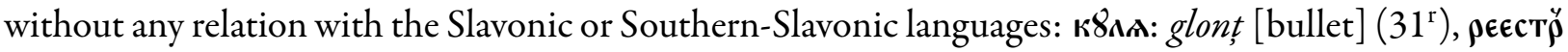
ими сал: rinduială, -ire [order]. The former is attested with its military meaning, according to GSBM (s.v. жyлs), as early as the $16^{\text {th }}$ century, while the latter is attested in Russian in 1665 (Vasmer, s.v. peecmp). Both examples were borrowed in Russian from Polish, either directly or through a Ruthenian intermediary. $\mathrm{MDA}_{2}$ attests glont in Costin's Chronicle, but it would be interesting to find out if any occurrences can be detected prior to 1670 .

Lupaşcu also noted an entry at the end of letter A and several entries at the end of B, of which some are worth mentioning:

- Безмезано: in zadar, in har [in vain]. Attested in Russian texts from the $18^{\text {th }}$ century, although the lexical family is also represented in Southern-Slavonic texts as early as the $10^{\text {th }}$ century, according to SJS, s.v. вєзмьзАьник'ъ and MIKL, S.v. вєзмьзАьно.

- Боты: cizme [boots]. After Vasmer, borrowed by Russian from Polish around the $15^{\text {th }}$ century, where it had in turn been borrowed from French. Non-attested in Bulgarian, where, for instance, ботуш is considered a borrowing from Romanian (DEB, s.v. бomym).

- Б8тылка: sticlă [bottle]. Also borrowed in Russian from French, either directly or through a Polish or Ruthenian intermediary.

- Вык: taur. Cf. ru./ bel. бък, but ucr./bg./sr-cr. бик. OCS выкъ.

- Бараваn: alăută [psaltery]. In DEB the word is considered a borrowing from Russian, although neither the period of the borrowing, nor the first attestation are specified.

- Багаж: odor din casă [jewel, precious thing from one's home]. In Vasmer (s.v. бazaßn) the first attestation dates from 1706. The term was borrowed from French via Polish or German. The Romanian translation is quite interesting, especially corroborated with the meaning 'bagaj, calabalîc' [baggage, stuff] for pilotă [quilt] in the area of Moldova ( $\mathrm{MDA}_{2}$, s.v. pilotă $)$.

- Башмаки ими ов8ви: рарисі [shoes]. According to Vasmer (s.v. башмак), the first word is borrowed from a Turanian language, such as Chagatai.

It is almost a certainty that most of the constant interventions to be found on the Staicu text belong to Lupaşcu. Comparing the writing at the beginning of $\mathrm{A}$, at the end of $\mathrm{B}$ and the side notes: выхованєц, питомєц: fecior de suflet [adopted son] $\left(58^{\mathrm{v}}\right)^{4}$, вєкша: veveriţă ${ }^{5}$ [squirrel], вравїл: stîlpare [sallows],

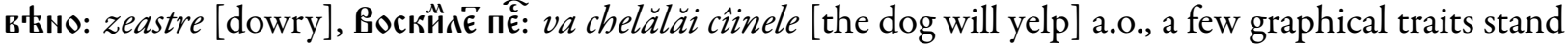
out. The capital $\mathbf{B}$ with protruding serif, $\boldsymbol{m}$ with three legs and a serif at the upper end of the left leg, the $\mathbf{6}$, the triangle-shaped $\$$, the $\uparrow$, the slightly bent 8 , the $ц$, the $\kappa$ with sinuous strokes, the overwritten $\rho$ with its leg bent at approximately 45 degrees from the horizontal, all these letters must have been written by the same hand or at least by people with extremely similar writing styles. Some words can be found on the entire Slavonic areal, such as в'кно or вравин. The former exists both in pre-modern Russian (SDI, s.v. вино) and in Bulgarian, its use being currently dialectal and obsolete. The latter is a Greek borrowing of a Southern-Slavonic ecclesiastic background, from $\beta \rho \alpha \beta \varepsilon i o v$, which meant 'prize' (accompanied by a palm-leaves garland, cf. palmares) in Slavonic and pre-modern Russian and then evolved towards 'palm-

\footnotetext{
${ }^{4}$ Cf. ucr. вихованець and bel. въхаванец.

${ }^{5}$ Word from Eastern Slavonic, not recorded in Bulgarian.
} 
tree branch' or any convenient substitute for the celebration of Palm Sunday (sRs 18, s.v. вpaвue). Other marginal glosses are related exclusively to the North-Eastern Slavic area. In the phrase Воскйм $\bar{\epsilon}$ пє்: va chelălăi cîinele [the dog will yelp], the verb is an Ukrainian regional version (SUM, s.v. скімлитu), where the vowels often close at [i]. It could be a Biblical gloss extracted from $E x, 11,7$.

\subsection{The an $\oint 0$ hand}

At the end of letter A we find two entries, one noted by Lupașcu一 ПрХивах: писмо Хранимицах: cămări de scrisori [letter rooms] —and one by an unknown author-an\$o: acum încă [now yet] —, an entry which is missing from BER and which notes a difficult term from the second book of Kings. In the Hebrew text (вHS, $2 R g, 2,14$ ) we find the combination ' $a \bar{p} h \bar{u}$, which SEPT leaves untranslated, rendering it by $\alpha \varphi \varphi \omega$. This phrasing was also challenging for the Slavic translators. Some Slavic texts render it as anфo - BIs ${ }^{6}$,

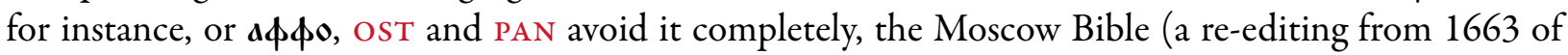
OST) omits it, yet notes $\mathbf{\alpha} \phi \dot{\mathbf{o}}$ on the side. SEPT.FRANK transcribes it as $\alpha \pi \phi \dot{\omega}$, whereas VULG translates it by "etiam nunc", meaning "right now".

This aпфо hand occasionally notes at the end of a letter definitions that present pleophony and at times complete the definitions provided by Staicu [врашно: bucate, mîncare [food] (Staicu), făină [flour] (апфо)].

\subsection{Hands of uncertain origin}

Other additions that seem to have a Ruthenian origin are виминица and вр8тка. The first example is actually a rewriting of a Staicu entry, placed one line above. The entry changes the $\boldsymbol{t}$ into $\mathbf{n}$ and slightly rephrases the translation. The intervention does not enrich the lexicon, yet the closing $\mathrm{k}$ indicates a speaker who was familiar with the Slavic languages spoken north of Moldova: rusn. бiльци, ucr. бiлuй, ceh. bily. However, south of the Danube, the isogloss of th divided the speakers into two large groups: eastern speakers, who pronounce an Iotated $a$ (bg. вял), and western speakers, who pronounce the sound as $e^{7}$. In

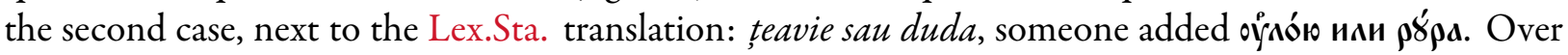
рьци there seems to be another level, with the letter $\mathrm{y}$. As rură is placed by DLRLC in the northern dialects (Moldova or Bukovina) and the etymon is a Ruthenian one, entered via Polish from the German Rohr $=$ 'țeavă' [pipe] (WSJP, s.v. rura), we can assume that the person who wrote that gloss was a scholar from the Northern part of the country. The lexicons Lex.Mosc., Lex.Pet., Lex.3473 and Lex.1348 translate it identically by țeavie de aramă [brass pipe], with no additional explanation, whereas Lex.Mard. erroneously notes indemînă [handy], probably under the influence of the previous entry в $\rho 8$ чєнїє.

On the first page for letter B, someone wrote the note ваџан's, pe bulgărie zice tată [in Bulgarian it is called father]. It is not clear whether the author is a Bulgarian speaker or, on the contrary, a Russian or Ruthenian speaker who notes a form he is unfamiliar with. The second hypothesis could be supported by the modern Ukrainian башmaн 'harbuzărie' [watermelon farm]. The Romanian manuscripts provide many examples of homophone pairs, both in the sections translated after BER, and in the other sections. It is also possible that the person who noted вaџan'ъ wanted to oppose the Bulgarian word to a Ruthenian one he was already familiar with.

In Lex.Pet., at the end of letter $\boldsymbol{B}$ there are three entries that cannot be found in any other dictionary, one of them being вєприни: agrişu [gooseberry bush]. Most probably, the scribe was already familiar with the term вєприна 'carne de mistreț' [wild boar meat] or 'femela porcului mistreț' [female wild boar], common to several Slavonic languages (ucr., sb. etc. cf. вєпрь: porcu, gliganu in Lex.Pet.) and wanted to add a regionalism that was specific to South-Western Ukraine, an adjacent area of the Northern Romanian areal (sUM, s.v. 2. веприна).

The most plausible scenario is the one according to which the first pages from the original Staicu lexicon had been lost or were not copied at all, and Lupașcu compensated these gaps subsequently, selectively extracting several definitions from at least two sources and completing the dictionary with a series

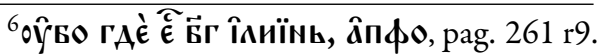

${ }^{7}$ Cf. mc. бeл, sb-cr. bèo, bijêl, bêl, but dialectally also бù̀.
} 
of definitions either at the beginning or at the end of a letter. His additions are generally placed at the beginning, right after the Staicu version, but in some cases, as it happens at the end of the letter $\boldsymbol{\Gamma}$, entries were added between two of his interventions. In this scenario, Lupașcu is also the one who eliminates two of Staicu's definitions - Язок and Ялєктор, as these had already been noted and translated in his reconstructed version.

Finally, on manuscript 312, at least two other owners left their graphic imprint in a later epoch. One of them, Jean de Talmatzy ${ }^{8}$, has rare interventions with equivalents in Latin and French. On page 50 the entry враздам: holdă [fields] is surrounded by a frame containing translations into Greek and Latin, French (champ laboure), Russian (землs обработаная) and Romanian (holdă, pămînt lucrat), to which another writer added a second frame containing the translations holdă sau dealniță.

\subsection{The Staicu hand}

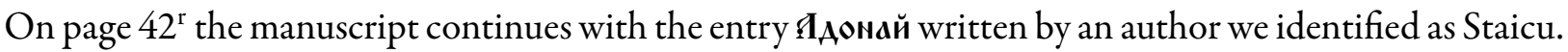
Our choice indicates that we accept the demonstration of Strungaru (1966), who attributed the paternity of this writing to the scribe from Tîrgoviște. The lexicon owes over $95 \%$ of its content to Staicu. After he finished processing the lexical material in BER, Staicu 2 adds 66 entries in which we can distinguish around five groups arranged in an approximately alphabetical order. The $\mathrm{Staicu}_{2}$ additions are not found in Lex.Pet., Lex.1348 or Lex.Mosc. (in Lex.3473 the letter A was not preserved, whereas in Lex.Mard. it is abruptly interrupted). With only two exceptions, Ira,o are also found in BER. Of these 64 entries, only five are new, the rest being duplicates of previously entries, some of them repeated even twice. It is almost as if we are looking at the notebook of a student who tries to learn a list of names, translating them repeatedly until he acquires them properly.

\section{Orthography}

Generally, the orthography of the Slavonic content in Romanian manuscripts differs from the one in BER. Even if we were to accept the hypothesis of a Romanian protograph which would be extremely faithful to BER, the successive antigraphs gradually took distance from it by applying the Slavonic orthography of Romanian redaction. In Lex.Sta., unlike BER, the combination breathing mark - acute accent (") is consequently placed on the initial vowel, consonants in adjacent positions coda - onset at the borderline between syllables are relatively consequently separated by Staicu with a payerok $\left(^{4}\right)$ or even an yer (IMьMa) - as it also happens in BER, owever, only sporadically-, in some instances the consonants are doubled: Lex.Sta. Яймакй vs BER Ямамикъ, and in some cases the Greek letters are phonetically adapted:

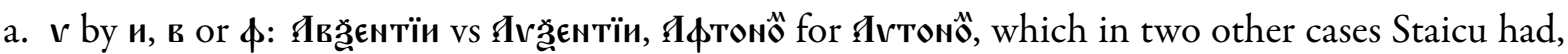

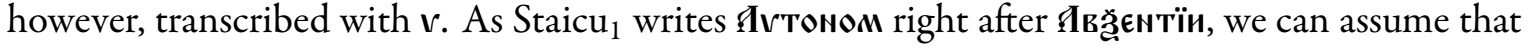
the scribe was either accustomed to write $\mathbf{B}$ instead of $\mathbf{v}$, or to pronounce it as such.

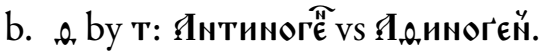

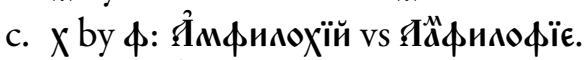

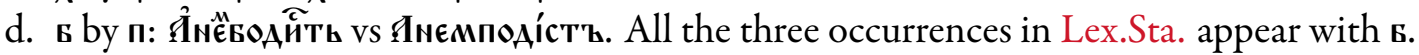

e. The group гг written $\mathbf{\mu r}$. Яга, we analyzed operated the replacement.

f. The groups liquid-yer $(\mathbf{\rho} \mathbf{b} / \mathbf{A} \mathbf{b} / \mathbf{\rho} \mathbf{b} / \mathbf{A} \mathbf{b})$ are often noted as we believe they used to be pronounced at the time, namely with the vocalization of the yer before the liquid sound, depending on the etymon: ăr $, e r, o r, a ̆ l, e l, o l$ etc.

In any case, substitutions as the ones emphasized above indicate the possibility that the lexicon was copied after dictation.

\footnotetext{
${ }^{8}$ Jean de Talmatzy wrote on March, 20, 1797 a note of appartenance on page $41^{\mathrm{r}}$.

${ }^{9}$ Both entries can be found in various Slavonic and Slavonic-Russian lexicons: oldlexicons.ru/node/2355 and oldlexicons.ru/node/1038.
} 
BER occasionally uses the spelling with vocalization when a word has a vernacular correspondent

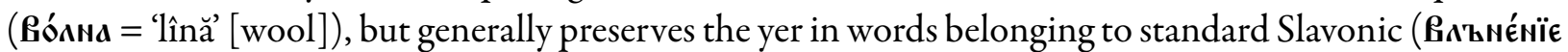

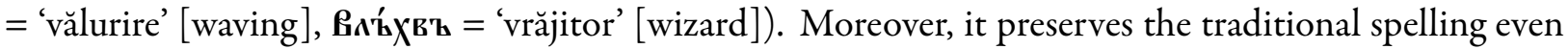
in cases where the pronunciation with metathesis and vocalization is obvious; for instance, between the

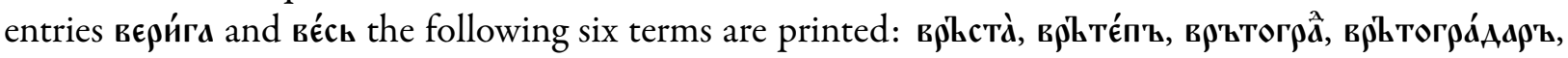
врһховвный and връшва̀. A significant detail is the fact that almost all these terms have an oversized/ tall version of the back yer. BER does not signal the vocalization using a tall back yer as a rule, yet this tendency can be observed, especially in the combination liquid sound-yer and it could reflect the orthography of the sources from which Pamvo Berynda extracted his definitions. With a single exception, our lexicons do not seem to use a tall yer, although they occasionally seem to distinguish between a vocalized yer and a final yer or between back yer and front yer, especially where the distinction is exemplified with minimal pairs in BER (Lex.Pet.: вóнł: afară [outside], вóнь: într-însu [in it/him]]; Lex.3473: вéçz: sat [village], réch: de tot [entirely]). This succession of six definitions occurs in all instances exactly as in BER between вєри́га and ве́сь. The entries are transcribed in Lex.Pet., Lex.1348, Lex.3473 and Lex.Mosc. also with a yer, either as in BER, or with metathesis (Lex.Mosc., Lex.3473: въртєпъъ; Lex.3473: върХовный), or by vocalizing the yer either selectively (Lex.1348, Lex.Pet.: вєрхо́вный; Lex.Pet.: вєӗтөпъ) or in all instances (Lex.Sta., except for the first entry - връшва).

The exception mentioned above is Lex.Mard. Whereas in all the other sources, as in all manuscripts, it is difficult to make a comprehensive inventory of the set of characters, in Lex.Mard. it is obvious that the scribe was familiar with the difference between tall and normal back yers, on the one hand, and the front yers, on the other hand. The tall back yer is also used in the group of words we analysed above from where

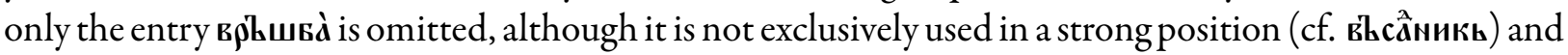
occasionally it is conveyed in an orthographic dimension that differs from BER (cf. в'́́ ́r. afară [outside], в́́нн: într-însul [in it/him]).

The Romanian manuscripts incorporate the graphic signs overwritten in BER in different degrees. An interesting case is that of the kamora $\left(^{\circ}\right)$, which marked for a long time in Slavonic the stress or the palatalization. In the first half of the $17^{\text {th }}$ century, Smotrițki grammars propose its introduction in the antistoechon, namely its transformation into a symbol that would emphasize morphological homophony. The new norm was rapidly adopted by the texts printed in Kiev (Kusmaul', 2017). For instance, Berynda

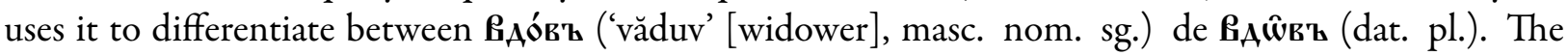
Romanian texts treat this pair in various ways. First of all, Lex.Mosc., Lex.Sta. and Lex.3473 have an

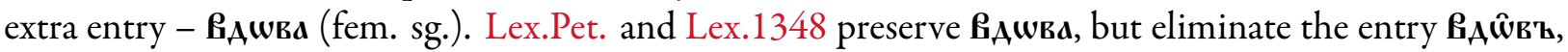
whereas Lex.Mard. preserves the version in BER, including the diacritics. Of all the entries, only $\mathbf{l}_{A} \hat{\mathbf{\omega}} \mathbf{B} \mathbf{a}$ in Lex.Mosc. can be described with no doubt as having an inverted breve ${ }^{10}$; on $\mathbf{B}_{\mathbf{A}} \mathbf{\mathbf { \omega }} \mathbf{\mathbf { B }} \mathbf{\mathbf { z }}$, the previous entry in the same manuscript, it rather looks like a smooth breathing mark. The author of Lex.1348 also seems to use a smooth breathing mark, Lex.Sta. and Lex.1348 use the acute accent, whereas Lex.Pet. adopts a slightly different orthographic convention, placing the acute accent on $\boldsymbol{o}$ and a double acute accent or a double grave accent on $\ddot{w}$. We cannot be sure that the Romanian authors had a good understanding of the use of the inverted breve in BER, although attempts were made, at least at the beginning, to transcribe it; in the instances they did not understand it, they chose to transcribe it according to their own norms.

Unlike in the case of BER, some proper names in Staicu are rendered with a suffix: Ira,

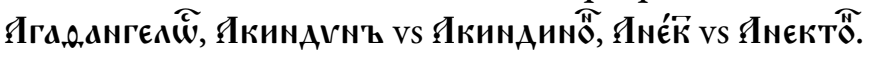

Proper names are often adapted to Romanian in Lex.Sta., the endings in ïa, $\mathbf{r a}$ being replaced by $\boldsymbol{n} \in$ and

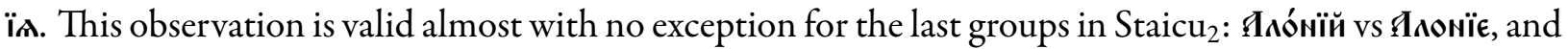
so on. Other Romanian lexicons are more conservative from this viewpoint.

Another error that could be explained in relation to BER is the spelling of

${ }^{10}$ This sign is called камора in Slavonic. I take this opportunity to thank Alexandr Andreev and father Nikita Simmons for their kindness and help in clarifying all these aspects related to the use of the inverted breve. 
in the history of the text, a Romanian scribe mistook the front yer for $\mathbf{o}$, and obviously the next step was to render it by $\boldsymbol{\omega}$.

All the manuscripts contain sections in which they do not follow exactly the order in BER. These cases are not necessarily frequent and could have been caused by negligence.

A series of hilarious errors in Lex.Pet. shed light on the work process of medieval scribes. Each Slavonic entry starts with a cinnabar, yet in some instances the initial is missing and in others it is placed before a Romanian word at the beginning of a line:

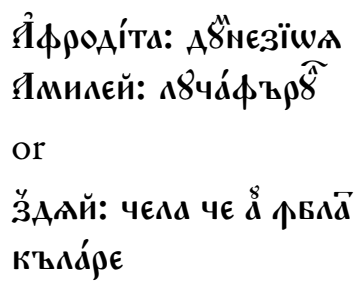

In the first example, the entry Afrodita had the explanation dumnezioaia milei, Luceafarul [the goddess of mercy, Morning Star]. The scribe added by mistake an A with cinnabar to the next line, turning one entry into two. In the second example, the letter II was obviously omitted. The scribe first wrote the entries without initial, then added the initial in cinnabar, thus making mistakes as the ones mentioned above. Strangely enough, he inserted a colon after milei, as if luceafärul would have actually explained the term Amilei, so it is actually possible that the error was not his, but it was instead perpetuated from another manuscript.

\section{Wording}

The entry which the first Romanian translators related to the Ruthenian text. In BER, Яваíй is not a separate entry, but part of the entry for Пва'й, the chief cook of King Ahab. Berynda specifies that Пваíй is a prophet celebrated on the $19^{\text {th }}$ of November and provides his description in Пода'ћмник ${ }^{11}$ : "cărunt, cu barbă nu prea mare, rotundă, părul vîlvoi, haina de culoarea ocrului, verzuie la poale, ținînd în mînă un sul” [greyhaired, with a round beard that was not so long, ruffled hair, with an ochre coat with green edges, holding a roll]. As the proper name is placed at the beginning of the line, the Romanian translator selected the first word of the quotation - G'kA'b and translated it, not necessarily accurately, by "cărunteațe". As the original version was no longer available, the other lexicons assumed this modification without any changes; Lex.Pet. even omitted the $\mathbf{B}$, as it is probably following a manuscript similar to Lex.Mosc., where $\mathbf{B}$ is overwritten in a way that pushes it towards the previous entry. This manner of translating at most one of the Ruthenian synonyms, namely the one the Romanian translator is most familiar with, can be observed in several instances in the Romanian lexicons. Another error can be observed at the entry Izmoá́ocra, where the Romanian manuscripts mistake the Ruthenian кази́тє⿻一ь 'cel care strică' [the one who breaks] for казнитель 'cel care chinuie' [the one who tortures] and consequently mistranslate it: muncitor, căznitor [harasser, one who submits to ordeals]. This strategy alternates with one in which the Ruthenian part is ignored, a (sometimes literal) translation being provided for the Slavonic entry.

The Ruthenian lexicographer explains the entry Як̌́ŕnd as follows: "Bolnav sau ce tinde spre pierdere. Bun și drept. Fapt. 18. Iul 14, ian. 20, feb. 13. Lat: aквí ^ג, vultur." [Ill or about to lose his life. Good and fair. Acts 18. Jul. 14, Jan. 20, Feb. 13. Lat: аквí^ג, eagle]. Staicu ${ }_{1}$, as all the other Romanian lexicons, translates Якима with bolnav [ill], whereas the Latin reference constitutes a separate entry. Staicu copies the term three times, and each time it is spelled and translated differently: 1. Якима: vultur [eagle], 2. Iкrad: bun și dirept [good and fair], 3. Якиิ̄a: bun sau prost [good or simple], the last two definitions being based on the second half of the explanation provided in BER.

\footnotetext{
${ }^{11}$ Slavonic manual of iconography, partially corresponding to the Byzantine guide Herminia.
} 
In the case of Icńprz, Lex.Sta., Lex.Pet., Lex.Mosc. and Lex.1348 (with the mention that the last manuscript in the series transcribes it Iри́č) combine the two entries in BER about which the Ruthenian scholar tells us that they are written differently in Hebrew, one with samekh and the other with shin.

There are often cases when the Romanian manuscripts contain additional words when compared to BER. Most of these words are extended paradigms of terms included in BER, various verbal forms, adjectives derived from nouns or nouns derived from adjectives. The Ruthenian printing contains grammatical notes related to aspects such as the voice of the verb, gender, etymological origin, orthographic explanations, and bibliographic references. Some of these notes are also conveyed in the Romanian texts. There are instances in which the Romanian author inserts such notes on his own initiative, without taking

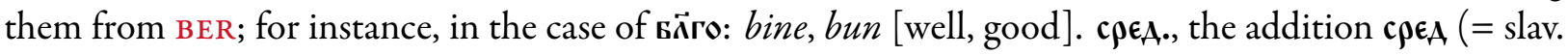
'neutral') has no correspondent in BER.

\section{Case study}

Let us consider a succession of 12 definitions printed in BER on column $355^{12}$ :

\begin{tabular}{|c|c|c|c|c|c|}
\hline BER & Lex.Mosc. & Lex.Pet. & Lex.Sta. & Lex.1348 & Lex.Mard. \\
\hline Iccáрїй & Яccápïn̆: banul & ศ̆ccápïn̆: banul & $\begin{array}{l}\text { Ăčcapïn: banul, } \\
\text { mangăr }\end{array}$ & - & Fileariu, mangăr \\
\hline Ясcáрїй & - & - & - & - & - \\
\hline IcTapć,o, & - & - & - & - & [end of letter] \\
\hline Яcmápmъ & - & - & - & - & \\
\hline Яспи́́рї̈̆ & $\begin{array}{l}\text { Icmí́িїй: de } \\
\text { steale }\end{array}$ & 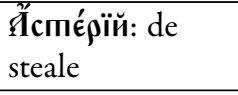 & $\begin{array}{l}\text { Ясперїи: de } \\
\text { steale }\end{array}$ & $\begin{array}{l}\text { Âcmé } \operatorname{sïй:~de~} \\
\text { steale }\end{array}$ & \\
\hline- & - & - & - & $\begin{array}{l}\text { f̂́čcápiïn: banul, } \\
\text { fost-au și niște } \\
\text { bani de lut și } \\
\text { piiale la Rîm de } \\
\text { s-au chiemat } \\
\text { assari. }\end{array}$ & \\
\hline Ястроло́́ð'а & $\begin{array}{l}\text { Ястроло́гїа: de } \\
\text { steale cetire }\end{array}$ & $\begin{array}{l}\text { Я̆cmроло́гїa: de } \\
\text { steale cetire }\end{array}$ & $\begin{array}{l}\text { Ястроло́гїа: } \\
\text { cetitor de steale }\end{array}$ & $\begin{array}{l}\text { Я̂строно́гїл: }^{13} \\
\text { cetire de steale }\end{array}$ & \\
\hline Ястроло́ґъ & $\begin{array}{l}\text { Ястроло́г'и: } \\
\text { cetitor de steale }\end{array}$ & - & - & 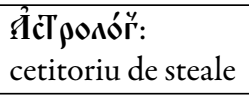 & \\
\hline- & $\begin{array}{l}\text { Icсарї̈̆: banul, } \\
\text { fost-au și niște } \\
\text { bani de lut și de } \\
\text { piiale la Rîm de } \\
\text { s-au chemat } \\
\text { assarii }\end{array}$ & $\begin{array}{l}\text { Йccápïn̆: banul, } \\
\text { fost-au și niște } \\
\text { bani de lut și de } \\
\text { piiale la Rîm de } \\
\text { s-au chemat } \\
\text { assarii }\end{array}$ & $\begin{array}{l}\text { กैčcapïn̆: banii, } \\
\text { fost-au și niște } \\
\text { bani de lut și de } \\
\text { piale la Rim de } \\
\text { s-au chiemat } \\
\text { assarii }\end{array}$ & - & \\
\hline Ясторономі́a & - & - & - & - & \\
\hline Яси́rкрї & $\begin{array}{l}\text { Яcvґкрї: mai } \\
\text { slăvit }\end{array}$ & 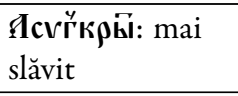 & $\begin{array}{l}\text { Îcírкрй: eresett } \\
\text { mai slăvit }\end{array}$ & 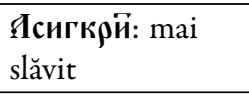 & \\
\hline กTiTà & - & - & - & - & \\
\hline ПТта́киа & ПТта́къ: crescut & $\begin{array}{l}\text { ПТта́s': } \\
\text { crescutu }\end{array}$ & $\begin{array}{l}\text { Ân̆manъ: } \\
\text { crescut }\end{array}$ & ศ̂m̆mẫ̂: crescut & \\
\hline
\end{tabular}

\footnotetext{
${ }^{12}$ BER assigned numbers to the columns, placing two on each page, so that for localization we used the same numbering system. However, we should consider the fact that the printing consisted of several stages, with various revisions, so the copies available today are not absolutely identical.

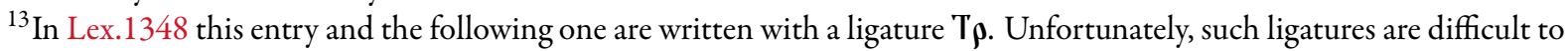
render in a text typed on a computer. For some fonts they are included in Private Area, a solution that could be regarded as acceptable, although suboptimal. The Ponomar font allows the display of some of the ligatures by inserting a zero width jointer (ZWJ: U+200D) between the following pairs of letters: $\mathcal{Z}_{\mathrm{A}}$ af, yet only in $\mathrm{ET}_{\mathrm{E}} \mathrm{X}$ and LibreOffice Writer, but not in Microsoft Word. Until better solutions are available, we inserted a ZWJ between тврьдо and рьци.
} 


\begin{tabular}{|c|c|c|c|c|}
\hline ЯТта́к'ъ & $\begin{array}{l}\text { ЯТта́хма: } \\
\text { stricătoriul }\end{array}$ & $\begin{array}{l}\text { ЯТта́ӑна: } \\
\text { stricătoriul }\end{array}$ & $\begin{array}{l}\text { Яl̆manïa: } \\
\text { stricătoriul }\end{array}$ & $\begin{array}{l}\text { Я̂ก̆máňna: } \\
\text { stricătoriul }\end{array}$ \\
\hline
\end{tabular}

The table emphasizes a series of aspects. First of all, Lex.Sta. is certainly a copy of at least the second generation of Romanian lexicons. The author's tendency is to reduce the number of definitions, while increasing the number of explanations. Staicu ${ }_{1}$ omits the entry Icmponór'b, but copies by mistake the corresponding explanation at the entry Icmponória. Right after this he repeats the mistake, translating Iิсі́гкрй by crescut [grown] from the following definition and correcting it by crossing it with a line.

The second obvious aspect is the fact that Lex.Mard. is the result of a different redaction.

The third aspect beyond doubt is that Lex.Mosc. cannot possibly be a copy after any of the manuscripts we analysed. The possibility of a filiation from Lex.1348 is significantly diminished by examples provided elsewhere.

Before an in-depth analysis of the entire lexicographic material is conducted, I shall only mention that the scheme proposed by Gînsac \& Ungureanu (2018) seem to reflect the reality better than the filiations previously suggested in literature. These two researchers from Iași have advanced the theory of the existence of at least one intermediary between BER and the group Lex.Pet., Lex.Sta. and Lex.3473. The data presented above suggests the profile of a manuscript that is very close to Lex.Mosc.. Besides the fact that Lex.Mosc. has some entries that are missing from the other manuscripts and the translations of the other lexicographic witnesses are convergent with the ones in Lex.Mosc., the spelling of the analysed entries is identical to the one in BER, whose letter variants are also often imitated. Unlike Lex.Sta., Lex.Pet. and Lex.1348, Lex.Mosc. does not use breathing marks on the initial; it does not replace T with m or $\mathbf{v}$ with $\mathbf{n} / \mathbf{I}$ and does not insert a payerok between neighbouring consonants, as Lex.Sta. and Lex.1348 (and occasionally Lex.Pet.), neither does it overwrite the final letter, or replace $\mathbf{a}$ by $\mathrm{a}$ as Lex.1348. Furthermore, it seems to be the only manuscript that occasionally reproduces $\boldsymbol{\Gamma}$ with an upwards serif from the Ruthenian

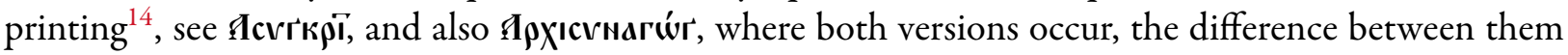
being obvious.

However, two of the details contained in the table oppose the identification of the assumed intermediary as Lex.Mosc. The first detail is related to the correction trescut in Lex.Sta. In Lex.Mosc. the

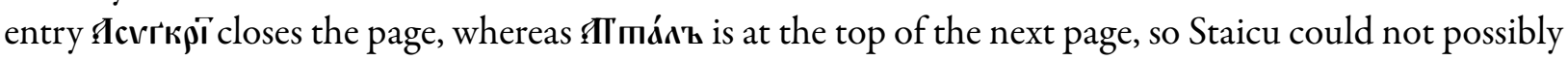
overlook it and go to the next definition. Nevertheless, I have to admit that one can as well imagine an explanation according to which the turning of the page causes the person copying the text to make a mistake. Moreover, it is not clear whether ITпа́nи in BER was transcribed with $\mathbf{и}$ or with $\mathbf{\mu}$ by the Lex.Mosc. copyist. I am almost sure that he opted for the wrong version. Fortunately, things are as clear as possible in the case of the other three manuscripts. Lex.Pet. and Lex.1348 erroneously transcribe with $\mathbf{N}$ and this aspect is confirmed by the presence of the payerok after $\boldsymbol{\Lambda}$. In this case, the entry in Lex.Sta., accurately and univocally transcribed with $\ddot{i}$, is revealed as important, as it motivates us to search for another protograph. Nonetheless, we can exclude neither the possibility of a correction by chance, nor that of an informed correction. Apart from his negligence, which can be frustrating at times, Staicu seems to have a good command of the Slavonic language and proves to be a competent scholar.

We should also mention the case of the proper name Яүиа́фскъ, transcribed erroneously by all the

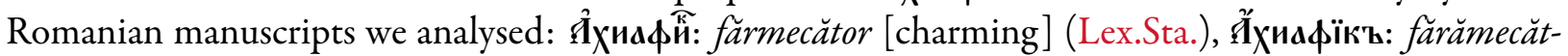

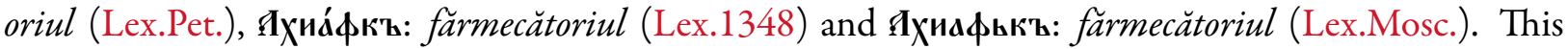
confusion is actually generated by Berynda himself, who wanted to enrich the entry Achsaph: Veneficus

\footnotetext{
${ }^{14}$ We have to specify that this type of Ge was used in the Slavonic books printed in the Polish-Lithuanian State Union to indicate $\mathbf{g}$ in words of Greek origin and was not part of the orthographic norms of the Slavonic spoken in the Romanian Principalities. Consequently, its occurrence on the Romanian territory can only indicate the contact with a Ruthenian original. For further details, see Andreev et al. (2015, p. 11). In BER this character has the height of a capital letter, its height being actually the criterion according to which we identified it in Lex.Mosc. Unfortunately, the font used in our article does not reflect this difference.
} 
[etc] from STEPH ${ }^{15}$ with its equivalent in the Slavonic canon. In the Slavonic versions of Ios, 1, 11 we

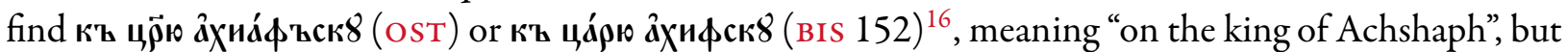
Berynda interprets the adjectival suffix used for geographical localization -ск as part of the name (cf. SEPT.FRANK: $\alpha \chi(\alpha \varphi$ ), and the Romanian copyists are thus challenged by a group of consonants they are unable to decipher. With regard to the aspects discussed above, the order of the events is relatively simple. Lex.Mosc. sees in BER a $\mathbf{b}$ instead of $\mathbf{c}$, Lex.1348 overwrites the yer, whereas Lex.Pet. and Lex.Sta. vocalize it at $\ddot{i} / \mathbf{n}$.

\title{
7. Conclusions
}

The Berynda lexicon represented a remarkable intellectual achievement and, in the actual case of the Romanian manuscript BAR 312, it was the source of a text used for over a century by several users who improved it permanently. The significant number of Romanian lexicons issued in a relatively short period of time illustrates the notable impact it produced. They could be the result of a synthesis between the Ruthenian version and a Slavonic dictionary of small dimensions. The structure of this hypothetical dictionary differs from the one of the current dictionaries and, as many other similar proto-dictionaries belonging to the Slavonic cultural space, was probably the result of a collection of glosses. We are actually facing a double challenge: on the one hand, to describe this hypothetical proto-dictionary as accurately as possible and on the other hand to retrace the filiations network of the Romanian dictionaries belonging to the Berynda family. With regard to the first challenge, we should conduct a more thorough investigation of the Slavonic manuscripts to be found in Romania or abroad, hoping that we have the chance of discovering a manuscript that would explain as well as possible the lexical lists included in the Romanian manuscripts. The second challenge makes us wonder not only how related our lexicons are to each other, but also how close they are to Berynda's edition. Besides the translation of the terms, other approaches are also worth exploring, which refer to the texts layout, the structure and organization of the lists, the interpretation, correction and perpetuation of errors. Apart from Lex.Mard., which has a slightly different writing and is also the oldest, Lex.Sta. is estimated by most researchers to be from an earlier date than all the other lexicons. However, the other manuscripts contain numerous elements that indicate an older edition and are closer to BER in many respects. Previous studies place Lex.Mosc. between the $17^{\text {th }}$ and the $18^{\text {th }}$ century, yet its orthography, inventory of terms and the layout of lists composing it indicate an edition that was very close to the first Romanian translation. Although we should remain cautious and keep the number of hypothetical manuscripts as low as possible, the significant variations between the lists, translations and errors renders the hypothesis of only one protograph quite unsatisfactory for the attempt to provide a valid explanation regarding the filiations of the $17^{\text {th }}$ century Romanian manuscripts.

\section{Bibliography}

\author{
A. Sources \\ BER = Pamvo Berînda, Аексіконъ славеноршсскій и именъ Тлькованїє, Kiev, 1627, [online]. \\ BHS = Biblia Hebraica Stuttgartiensia, Deutsche Bibelgesellschaft, 1997, [online]. \\ віs = Ветхого Завета Книги: Моисеевы плть, Иисуса Навина, Судей, Руфь и четьце Царства. Маnuscript copied in \\ Bistrița, kept today at the State Library of Russia, F. 256, no. 29, year 1537, [online]. \\ Lex.1348 = The lexicon in the Romanian manuscript 1348 from BAR $\left(1-84^{\mathrm{v}}\right)$; without the title page. \\ Lex.3473 = The lexicon in the Romanian manuscript 3473 from BAR $\left(1-369^{\mathrm{v}}\right)$; without the title page.

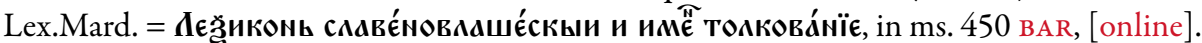 \\ Lex.Mosc. $=$ Slavonic-Romanian Lexicon, RGADA, collection 188, no. 1380, without the title page.

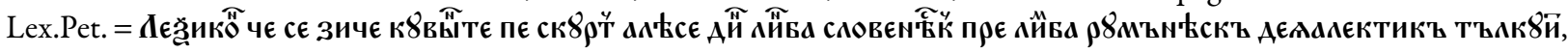 \\ BNR, OP Q.XVI.5.

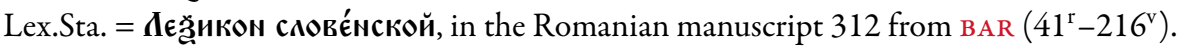

\footnotetext{
${ }^{15}$ Work from which Berynda borrows a great part of the proper names material.

${ }^{16}$ lib-fond.ru.
} 
OST $=$ ОСТРОЗЬКА БІБАІЯ [Ostrog Bible]. Edition with transcription, facsimile and parallel Ukrainian translation supervised by archimandrite Rafail (Роман Торконяк), Liov, 2006.

PAN = Vechiul Testament $[$ The Old Testament] translated by Danil Andrei Panoneanu, Romanian manuscript 4389 BAR, [online].

SEPT = Septuaginta. Id est vetus Testamentum Grace iuxta LXX Interpretes, A. Rahlfs (ed.), Wurttembergische Bibelstalt, 1971, [online].

SEPT.FRANK = TH $\Sigma \Theta E I A \Sigma \Gamma P A \Theta H \Sigma$. Divine scripture, nempe veteris ac novi testamenti, Frankfurt, 1597.

STEPH = Robert Stephanus, Hebrea, Chaldea, Greca et Latina nomina virorum, mulierum, populorum, idolorum, urbium,

fluuiorum, montium, caterorumque locorum que in Bibliis leguntur, restituta, cum Latina interpretatione, 1537.

vULG = Biblia Sacra Vulgate editionis, Sixti V Pontificis Maximi jussu recognita et edita, Typographus Vaticanus, 1598, [online].

\section{B. Dictionaries}

DEB = Български етимологичен речник [Bulgarian Etymological Dictionary], ed. ВА. И. Георгиев et al., 9 vol., Sofia, 1971present.

DLRLC = Dicționarul limbii române literare contemporane (sub direcția prof. univ. Dimitrie Macrea și acad. Emil Petrovici).

Volumul I: $A-C, 1955$; volumul al II-lea: $D-L, 1956$; volumul al III-lea: $M-R, 1957$; volumul al IV-lea: $S-Z, 1958$,

Editura Academiei, [București].

GSBм = Гістарыцны слоўнік беларускай мовыє [Historical Dictionary of Belarusian Language], Minsk, 1986, [online].

$\mathrm{MDA}_{2}=$ Micul Dicționar Academic [Little Academic Dictionary], $2^{\text {nd }}$ edition, red. M. Sala, I. Dănăilă, Univers Enciclopedic

Publishing House, București, 2010.

MIKL = Miklosich, Fr. (1862-1865). Lexicon Paleslovenico-greco-latinum, Guilelmus Braumueller, Vindobonæ, [online]. SDI $=$ Словарь древнерусского языка $(X I-X I V$ вв. $)$ [Dictionary of old Russian $\left(11^{\text {th }}-14^{\text {th }}\right.$ centuries $)$, Academia de Științe a

URSS, Institutul limbii ruse, Editura Русский язык, Moscova, 1988.

SJS = Elektronický slovnik jazyk staroslovénského [Electronic Dictionary of Old Slavonic], digital dictionary created within the

Gorazd Project under the patronage of the Czech Academy of Science's Institute of Slavonic Studies, [online].

SRs 18 = Словарь русского языка XVIII века [Dictionary of the $17^{\text {th }}$ century Russian], Academia de Științe a URSS, Institutul limbii ruse, Editura Наука, Sankt Petersburg, 1984-1991.

SUм = Словник української мови [Dictionary of the Ukrainian Language], 11 vol., Editura Наукова Аумка, Kiev, 1970-1980.

Vasmer = Vasmer, M. (2004). Этимологиический словарь ру́сского язька [Etymological Dictionary of the Russian Language], ed. О. Н. Трубачёв, АСТ.

WSJP = Wielki stownik jezyka polskiego [The Great Dictionary of the Polish Language], ed. P. Żmigrodzki, online dictionary curated by the Polish Language Institute of the Polish Academy of Sciences, 2012-present.

\section{Secondary literature}

Andreev, A., Shardt, Y. \& Simmons, N. (2015). Church Slavonic Typography in Unicode, Unicode Technical Note \#41, [online].

Ciobanu, Șt. (1914). Славяно-румьнский словарь библитеки Московскаго Общества Истории и Аревностей по 240

[Slavonic-Romanian Dictionary found in the Moscow Society of History and Antiquity], in "Русский филологический вестникъ", LXXI (1), p. 75-88.

Crețu, G. (ed.) (1900). Mardarie Cozianul. Lexicon slavo-românesc și tîlcuirea numelor din 1649, Edițiunea Academiei Române, Institutul de Arte Grafice "Carol Göbl”, Bucuresci.

Gînsac, A-M. \& Ungureanu, M. (2018). La lexicographie slavonne-roumaine au XVIIe siècle, in "Zeitschrift für romanische Philologie", 134 (3), p. 845-876.

Gînsac, A-M. \& Ungureanu, M. (2019). Lexiconul de la Moscova în raport cu celelalte lexicoane slavo-române din secolul al $X V I I-l e a$ [The Moscow Lexicon in relation with other Slavonic-Romanian lexicons of the $17^{\text {th }}$ century], in "Philologica Jassyensia”, XV (2), p. 245-258.

Карпов, А.П. (1877). Азбуковники или алфавиты иностранныхречей по спискам Соловецякой библиотеки [Lexicons and Alphabets of foreign languages in Solovetsky Monastery's Library], Printing House of the Imperial University, Kazani.

Ковтун, $\Lambda$. С. (1989). Азбуковники XVI-XVII вв.: Старшал разновидность [16 to $17^{\text {th }}$ century lexicons. Old Redaction], Editura Наука, Sankt Petersburg.

Kusmaul', S. (2017). Evolution of the Functions of the Kamora Sign In Liturgical Books from the Late 16th To the First Half of the 17th Centuries, in “St.Tikhons' University Review”, series III. Philology, 51, p. 21-47.

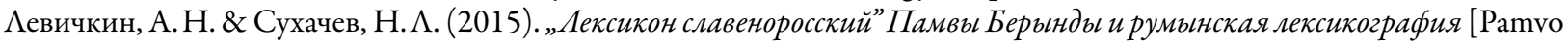
Berynda's "Slavenorussian Lexicon" and the Romanian Lexicography], in Aкадемик A. А. Шахматов: жизнь, творчество, научное наследие. Сборник статей к 150-летию со дня рождения ученого, еd. О. Н. Крылова, М. Н. Приемышев, Sankt Petersburg.

Strungaru, D. (1966). Inceputurile lexicografiei române [Inceptions of Romanian Lexicography], in "Romanoslavica", XIII, p. $141-158$.

Strungaru, D. (1973). Staicu Grămăticul. Contribuții la istoria scrisului românesc din secolul al XVII-lea [Staico the Amanuensis. Contributions to the history of Romanian writings of the $17^{\text {th }}$ century], doctoral thesis, University of Bucharest's Typolitography Center, Bucharest. 


\section{Acronyms}

BAR = Biblioteca Academiei Române [Romanian Academy Library]

BNR = Biblioteca Națională a Rusiei [Russian National Library]

RGADA = Arhiva Rusă de Stat a Actelor Vechi [Russian State Archive of Old Documents] 